\title{
PHYSIOLOGICAL EFFECTS OF MANNOSE IN Nannotrigona (Scaptotrigona) postica (HYMENOPTERA, APOIDEA, MELIPONINAE).
}

\section{FERNANDO SÉRGIO ZUCOLOTO and MARIA CECILIA TORRES PENEDO}

\author{
Departamento de Biologia, Faculdade de Filosofia, Ciências e Letras de \\ Ribeirão Preto, U.S.P. Brasil.
}

\begin{abstract}
$A B S T R A C T$
The physiological effects of mannose in Nannotrigona (Scaptotrigona) postica were investigated. Results showed that mannose is toxic to the bees. Glucose protection dgainst mannose poisoning was also evidenced. Increasing the glucose content in the diet decreased the toxicity of mannose fed to newly emerged adults. An utilization of such carbohydrate toxicity, in biological control, is proposed.
\end{abstract}

\section{SUMARIO}

Foram estudados os efeitos fisiológicos da manose em Nannotrigona (Scaptotrigona) postica. Os resultados mostraram que a manose c tóxica para estas abelhas. A glicose protege contra esta toxidez, sendo que aumentando-se a quantidade de glicose na dieta, diminui a toxidez da manose. Foi proposta uma utilização da toxidez de carbohidratos no controle biológico.

\section{INTRODUCTION}

Staudenmeyer (1939) evidenced that mannose is a toxic carbohydrate to Apis mellifera; Sols, Cadenas and Alvarado (1959) concluded that this toxicity is caused by the lack of an enzyme, phosphomannoseisomerase, that is able to transform mannose-6-P to fructose-6-P. These authors also concluded that there exists a competition between mannose-6-P and fructose-6-P by the enzyme phosphoglucoseisomerase. These positions were contested by Baker and Lehner (1974). Zucoloto (1972) fed various groups of bees (Apis mellifera) with different proportions of glucose and mannose and concluded that the survival of the bees is directly related to the amount of glucose in the mixture.

Although the biochemical effect of mannose to Apis mellifera is still not clear, we suppose from our results that an enzymatic competition between glucose-6-P and mannose-6-P is very likely to occur.

Our aim in this investigation, is to detect the physiological effects of mannose in Nannotrigona (Scaptotrigona) postica. 


\section{EXPERIMENTS}

Bees used in this investigation were callow bees which had emerged from combs placed in boxes maintained at ca. $29^{\circ} \pm 1^{\circ} \mathrm{C}$ and $60-70 \%$ relative humidity.

Each group of 20 bees was confined to a $3 \times 3 \times 4 \mathrm{~cm}$ wooden box and each experiment was made twice. The wooden boxes had two holes through which food to be tested and tap water were given to the bees. Small containers, daily cleaned, were adapted to the holes.

The Mann-Whitney ranking test was applied to the results.

Experiment 1: Is mannose an utilizable carbohydrate by Nannotrigona (Scaptotrigona) postica?

To answer this question, we fed 3 groups of bees, as follows: a) $15 \%$ sucrose solution; b) $15 \%$ mannose solution; c) tap water. The life span of the bees was computed. The results are shown in Table I.

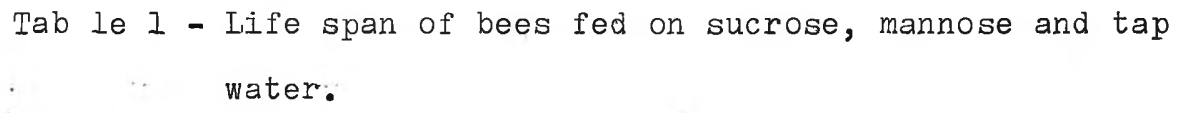

\begin{tabular}{|c|c|c|}
\cline { 2 - 3 } \multicolumn{1}{c|}{} & \multicolumn{2}{c|}{ Life span in days } \\
\hline COMPOUND & $1^{\text {st }}$ experiment & $2^{\text {nd }}$ experiment \\
\hline $15 \%$ sucrose & $19.30 \pm 5.23$ & $21.35 \pm 1.46$ \\
\hline $15 \%$ mannose & $1.75 \pm 0.43$ & $1.45 \pm 0.51$ \\
\hline Tap water & $1.45 \pm 0.50$ & $1.60 \pm 0.50$ \\
\hline
\end{tabular}

- The statistical analysis showed that the life span of the bees fed $15 \%$ sucrose (group a) is superior to the others; those of groups $b$ and $c$ were similar. These results indicate that mannose is not utilized by Nannotrigona (Scaptotrigona) postica.

Experiment 2: The non utilization of mannose by the bees is due to non-ingestion?

In this experiment, the bees remained $24 \mathrm{~h}$ without food, an then received a $15 \%$ mannose solution, stained with Congo red $1 \%$. After $6 \mathrm{~h}$ the bees were dissected in $0,9 \% \mathrm{NaCl}$ and their digestive tracts were examined. All 40 bees showed their digestive systems stained; so, mannose is ingested by the bees. 
Experiment 3: Would mannose be ingested by the bees but not sufficiently to sustain a normal survival?

In this experiment, the bees were fed through 2 pipettes, one containing a $15 \%$ sucrose solution and the other a $15 \%$ mannose solution. The consumption of the two solutions was measured during 5 days. The bees were changed daily because of the high mortality of the bees fed on mannose. The results are shown in Table 2 and there are no statistical difference between the 2 groups. The experiment shows that mannose is ingested very well by the bees.

Table 2 - Consumption of $15 \%$ mannose and $15 \%$ sucrose by bees. Consumption/bee/day/ml.

\begin{tabular}{|c|l|l|l|l|l|}
\hline COMPOund. & $1^{\text {st }}$ day & $2^{\text {nd }}$ day & $3^{\text {rd }}$ day & $4^{\text {th }}$ day & $5^{\text {th }}$ day \\
\hline $15 \%$ mannose & 0.022 & 0.022 & 0.023 & 0.021 & 0.022 \\
\hline $15 \%$ sucrose & 0.021 & 0.023 & 0.019 & 0.023 & 0.022 \\
\hline
\end{tabular}

Table 3 - Life span of bees fed on sucrose and on a mixture of sucrose and mannose.

\begin{tabular}{|c|c|c|}
\cline { 2 - 3 } \multicolumn{1}{c|}{} & \multicolumn{2}{|c|}{ Life span in days } \\
\hline $\begin{array}{c}\text { COMPOUND } \\
+\end{array}$ & $1^{\text {st }}$ experiment & $2^{\text {nd }}$ experiment \\
\hline $15 \%$ mannose & $1.60 \pm 0.42$ & $1.70 \pm 0.50$ \\
\hline $15 \%$ sucrose & $16.75 \pm 3.75$ & $17.80 \pm 3.25$ \\
\hline
\end{tabular}


Table 4 - Life span of bees fed on different proportions of glucose and mannose.

\begin{tabular}{|c|c|c|c|}
\hline & \multicolumn{2}{|c|}{ Iife span in days } \\
\hline \multicolumn{2}{|c|}{ COMPOUND } & $I^{\text {st }}$ experiment & $2^{\text {nu }}$ experiment \\
\hline $\begin{array}{r}\text { GIucose } \\
+ \\
\text { Manrose }\end{array}$ & $\begin{array}{r}14.25 \% \\
0.75 \%\end{array}$ & $20.00 \pm 4.61$ & $19.62 \pm 4.41$ \\
\hline $\begin{array}{r}\text { Glucose } \\
+ \\
\text { Mannose }\end{array}$ & $\begin{array}{r}13.50 \% \\
1.50 \%\end{array}$ & $14.80 \pm 6.72$ & $16.90 \pm 3.34$ \\
\hline $\begin{array}{r}\text { Glucose } \\
+ \\
\text { Mannose } \\
\end{array}$ & $\begin{array}{r}12.75 \% \\
2.25 \% \\
\end{array}$ & $9.53 \pm 2.73$ & $13.43 \pm 2.80$ \\
\hline $\begin{array}{r}\text { Glucose } \\
+ \\
\text { Mannose }\end{array}$ & $\begin{array}{r}12.00 \% \\
3.00 \%\end{array}$ & $6.73 \pm 2.82$ & $8.50 \pm 2.20$ \\
\hline $\begin{array}{r}\text { Glucose } \\
+ \\
\text { Mannose } \\
\end{array}$ & $\begin{array}{r}11.25 \% \\
3.75 \% \\
\end{array}$ & $6.05 \pm 2.66$ & $790 \pm 1.90$ \\
\hline $\begin{array}{r}\text { Glucose } \\
+ \\
\text { Mannose } \\
\end{array}$ & $\begin{array}{r}10.50 \% \\
4.50 \% \\
\end{array}$ & $4.93 \pm 0.26$ & $5.70 \pm 1.55$ \\
\hline $\begin{array}{r}\text { Glucose } \\
+ \\
\text { Mannose }\end{array}$ & $\begin{array}{l}9.75 \% \\
5.25 \%\end{array}$ & $4.67 \pm 1.05$ & $5.25 \pm 1.40$ \\
\hline $\begin{array}{r}\text { Glucose } \\
+ \\
\text { Mannose }\end{array}$ & $\begin{array}{l}9.00 \% \\
6.00 \%\end{array}$ & $3.73 \pm 0.46$ & $5.00 \pm 1.60$ \\
\hline $\begin{array}{r}\text { Glucose } \\
+ \\
\text { Mannose } \\
\end{array}$ & $\begin{array}{l}8.25 \% \\
6.75 \% \\
\end{array}$ & $2.93 \pm 0.26$ & $2.53 \pm 0.60$ \\
\hline $\begin{array}{r}\text { Glucose } \\
+ \\
\text { Mannose } \\
\end{array}$ & $\begin{array}{l}7.50 \% \\
7.50 \% \\
\end{array}$ & $1.80 \pm 0.51$ & $2.00 \pm 0.72$ \\
\hline Glucose & $15 \%$ & $21.60 \pm 1.24$ & $19.50 \pm 1.18$ \\
\hline Manncse & $15 \%$ & $1.40 \pm 0.51$ & $1.25 \pm 0.44$ \\
\hline
\end{tabular}


Experiment 4: Would mannose be toxic to the bees?

In this experiment, we fed daily 2 groups:

a) control group - $15 \%$ sucrose solution ( $1 \mathrm{ml} /$ day).

b) experimental group - a mixture of $15 \%$ sucrose solution $(0.5 \mathrm{ml})$ and $15 \%$ mannose solution $(0.5 \mathrm{ml})$.

Any decrease in the survival time of the experimental group when compared to the survival of the control group was interpreted as a toxic effect. The results are summarized in Table 3 .

The results of this experiment show that mannose is really toxic to the bees.

Experiment 5: Does glucose really protect bees against mannose poisoning?

In this experiment we fed 9 groups with different proportions of glucose and mannose solutions. We had 2 control groups, one fed only with glucose solution and the other fed with mannose solution. Table 4 summarizes the alimentation given to the bees and the results of this experiment.

The results show that the life span of the bees is in direct relation to the amount of glucose in the mixture. The same results were obtained with Apis mellifera.

\section{DISCUSSION}

Based on our experiments, we can conclude that mannose is a toxic carbohydrate to Nannotrigona (Scaptotrigona) postica. The biochemical causes of this toxicity are still not determined and although our experiments are at a physiological level, we bleieve that there is a competitive inhibition between mannose and glucose. On the other hand, the toxic sugars may act as antimetabolites, possibly by interfering with sugar transport (Nettles, 1972).

Researches to ascertain whether a carbohydrate is toxic to an insect are important in two aspects:

1) As an aid in phylogenetic researches. For instance, mannose is toxic for all Hymenoptera studied, but it is not toxic for Diptera.

2) The toxicity of a carbohydrate can be utilized in biological control. Biological control through nutrition is being proposed by several authors (Pratt, House and Mansing, 1972), mainly with industrialized food. In relation to carbohydrate our idea is: if the carbohydrate is toxic to an insect which is harmful to agriculture but not toxic to man, its application is viable in the plantation. Evidently, this idea is based on a theoretical ground and many additional studies must be done, for instance: laboratory studies on the toxicity of the carbohydrate, man's tolerance to the carbohydrate and mainly the operational cost of the method.

\section{REFERENCES}

BARKER, R. J. and $Y$. LEHNER, 1974 - Acceptance and sustenance value of naturally occuring sugars fed to newly emerged adult workers of honeybees. $J$. Exp. Biol. 187 : 277-286. 
NETTLES, W. C. 1972. Toxic sugars and longevity of Anthonomus grandis. I, Insect physiol. 18: 1107-1113.

PRATT, J. J., H. L. HOUSE and A. MANSING, 1972 . Insect control strategics based on nutritional principles. Insect and mite nutrition: 651-668.

STAUDENMEYER, T., 1939. Die Giftigkeit der Mannose fur Bienen und andere Ingekten. Z. vergl. Physiol. 26: 644-668.

SOLS, A., E, CADENAS and F. ALVARADO, 1959 - Enzymatic basis of mannose toxicity in honeybees. Ścience 131: 297-298.

ZUCOLOTO, F. S., 1972 - Estudo "in vivo" da toxidez da manose em Apis melltfera. Livro homenagem an Dr. Warwick E. Kerr, Rio Claro: 311-316. 